\title{
Apprenticeship System and Employees' Performance: A Bird's Eye View of Small and Medium Enterprises in Benue State, Nigeria
}

\author{
EKOJA, Geoffrey Owoicho, UGBA, Vivien Anna, PETERSIDE, Godwin Iyuwuna Dodd, ANI, \\ Solomon Ikechukwu
}

\begin{abstract}
The study examines the apprenticeship system and employees' performance in small and medium enterprises in Benue State, Nigeria. The study objectives include: to determine the relationship between time spent by the employee in apprenticeship and rate of task accomplishment; and to examine how apprenticeship training influences employees' dedication to business activities. The study randomly sampled 215 employees across 20 Small and Medium Enterprises in Benue State. The study used a structured questionnaire for data collection. Data on research questions were analysed using frequency count and percentage, while hypotheses were tested using Pearson product-moment correlation and linear regression analysis. The study found that the duration of apprenticeship significantly influences the rate of task accomplishment by Small and Medium Enterprise employees in Benue State. Likewise, the study established that frequent training and re-training through apprenticeship creates a sense of belonging and greater dedication. The study recommended that Small and Medium Enterprise operators should intensify the organisation of training with training institutes as cover for the lack of skills and technicalities during training.
\end{abstract}

Keywords: Apprenticeship System, employee performance, task accomplishment, job dedication.

\section{INTRODUCTION}

Generally, nothing is more precious to the small and medium enterprises than pride in having sets of developed and highly skilled employees. One of the expected roles of the human resource management unit in every organisation is to ensure that all employees, irrespective of their backgrounds, are subjected to further skills development through dedicated training and apprenticeship. Udu [28] expressed that it is expected of employees to seek the required skills and operational technicalities, either through dedicated training or an apprenticeship. Steedman [26] opined that apprenticeship is a form of on-the-job training which entails systematic training of a new generation of practitioners in a

Revised Manuscript Received on November 22, 2019.

EKOJA, Geoffrey Owoicho, Department of Management, University of Nigeria Enugu Campus, Enugu State, Nigeria

PETERSIDE, Godwin Iyuwuna Dodd, Department of Management, University of Nigeria Enugu Campus, Enugu State, Nigeria

ANI, Solomon Ikechukwu, Department of Management, University of Nigeria Enugu Campus, Enugu State, Nigeria

UGBA, Vivien Anna, Department of Management, Benue State University, Makurdi Benue State, Nigeria

Corresponding Author: ekojageoffrey2014@gmail.com. trade or profession to be able to progress. Through on-the-job training some specific skills are supplemented after engagement of particular employees. Through apprenticeships the practitioners can also gain a licence to formally practise a planned profession or trade. The continuing changes in the tastes of consumers as well as technological advancement on a daily basis is forcing organisations to seek new design techniques which require new production skills from employees. Thus, apprenticeship is one of the means which most organisations could adopt to train and retrain their employees to equip them with appropriate design knowledge and skills that will meet the tastes of customers and curtail excessive waste of resources during production and delivery processes. Apprenticeship is considered by Werwatz [30] as any training programme that combines vocational education with work-based learning for a particular occupational skill that can transform an individual from unskilled to semi-skilled and skilled in a particular field or discipline. At organisation level, apprenticeship can mean training assistance offered by a firm to upgrade its employees to meet the requisite skills or adjust to the technicalities needed for a new line of business.

One of the beauties of apprenticeship is the ability of the enterprise to save costs in training its personnel. Since most of the training is usually being carried out concurrently during operation, such a training mode helps the apprentices to learn more about their trade or profession and acquire new emerging skills related to their activities for productivity. Ryan, Wagner, Teuber and Backes-Gellner (2010) [22] express that at most times, the apprenticeship is being organised for the employees in exchange for their continued labour for an agreed period after they have achieved measurable competencies. Whenever an organisation chooses to place some of its employees on apprenticeships, the chances are for mutual gains on both the part of the employee who attains a new level of skills and experiences and on the part of employers who gain more competent hands to get things done.

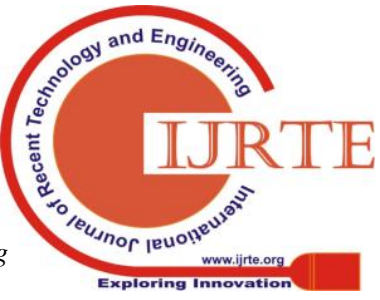


Even though the enterprises do benefit significantly from staff training and development, one could quickly notice that management usually shies away from placing their staff on apprenticeship training. Thus, what is mostly observed among the practices of different enterprises is to send their staff for further training outside their establishment, such as workshops, seminars and even skills acquisition training. The argument by many authors against the apprenticeship training includes: lack of dedication by employees due the unchanged environment; minimal skills gained due to previous relationships with enterprise-based supervisor; and waste of resources on the part of the organisation as objectives of the training could not be met (Owusu-Acheampong, 2015 [19]; Lulu and Riyanto, 2011) [14]. However, studies by Chris-Hasluck, Baldauf and Geoff (2015) [5] and Kenton (2011) [10] independently supported the apprenticeship system and pointed at benefits such as the ability to train staff on the specific skills required in the firms, ability to monitor the staff under training which leads to cost-effectiveness as well as chances for the firm to discover new skills and new areas of production through trained staff. Thus, the conclusion drawn by different authors, in support or against the apprenticeship, requires further empirical study to have further insight into actual benefits of the apprenticeship training on the employees in terms of their performance. Therefore, the current study is an empirical effort to examine whether the apprenticeship system and employees' performance in small and medium enterprises in Benue State is improving or not.

$\mathrm{Obj}_{1}$ : To determine the relationship between time spent by an employee in apprenticeship and rate of task accomplishment in small and medium enterprises.

$\mathrm{Obj}_{2}$ : To examine how apprenticeship training affects employee dedication to business activities in small and medium enterprises.

\section{REVIEW OF RELATED LITERATURE}

\section{Conceptual Framework}

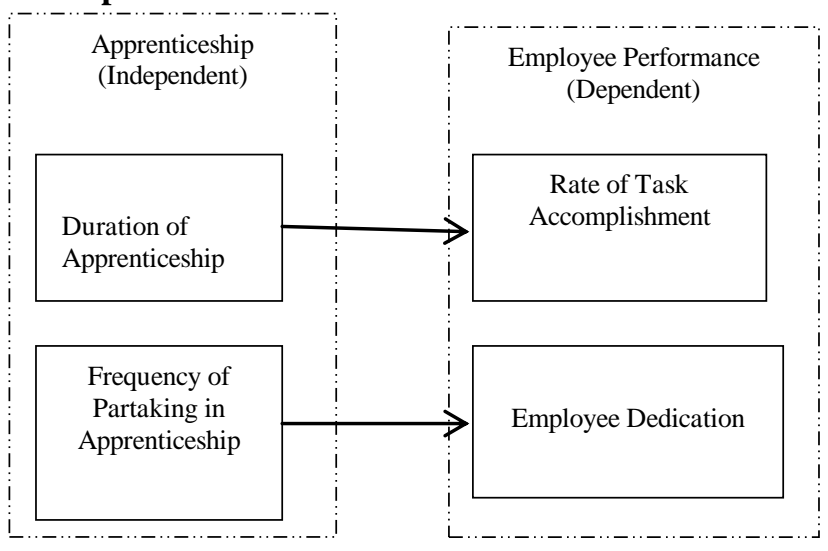

Concept of Apprenticeship

Apprenticeship training is one among the various routes through which an individual can become a skilled worker, through long- or short-term on-the-job training (Gary Dessler, 2008). Historically, the apprenticeship system of training could be traced back to the middle Ages period. Apprenticeship was then initiated by different craft guilds and community administrators with dedicated supervision through different craft masters. The master craftsman (expert craftsman) during the time has the right to engage young individuals to offer services for their craftwork with little or no amount paid, only that the master craftsman usually provided food, shelter and training for such staff. This arrangement was expected to turn the employees into experts in some years through which he/she could become craft masters as well. Chris-Hasluck, Baldauf, and Geoff, (2015) [5] recount that the apprenticeship at its inception was an inexpensive form of labour that exchanged payment of service with provision of food, lodgings and formal training in the craft.

In those days, most apprentices were males, while female apprentices are familiar in trades such as seamstress, tailor, cordwainer, baker and stationer. The ages of apprentices differ but are mostly within the age range of $14-20$ years (Ryan et al., 2010) [22]. At that time, it is expected of apprentices to depart their towns or households to live in the master craftsman's household. According to Lulu and Riyanto (2011) [14] almost all apprentices do aim to become master craftsmen themselves after finishing their training years. However, some ended up acquiring little while others could not come out as master to even start their own workshop. Meanwhile those who succeeded in acquiring the necessary skills usually became freemen in their city and regarded as responsible within society. This motivated numbers of others to embark on the similar journey to win their freedom and recognition.

In Benue State, Nigeria, almost all trades have modes of apprenticeship and apprentice labour responsible for vast industrial activities among early artisans in Nigeria. According to Wolter and Paul (2011) [31] the length of apprenticeship could be as long as ten years, while in most cases, three years is set as the limited time an apprenticeship could spend before being considered an expert. As in the practices of Middle Age apprenticeship, the apprentices are to live with their master to learn everything the master is doing including lifestyle. Akpalu (2012) [2] argued that through the close-marking knowledge-seeking system of apprenticeship most apprentices develop generic attitudes that make them traceable to their master and even their grandmaster. Owusu-Acheampong (2015) [19] asserts that since the inception of trade apprenticeship in Ghana and 
Nigeria, the attitude variant was uncommon, the trained apprentices live similar life patterns to their masters and get in touch with their masters throughout their lifetime.

The apprenticeship at the wake of the industrial revolution changed significantly from a mutual benefit agreement to an industrial requirement condition that all employees intending to work with such an industry have to gain. During the industrial revolution, human labour was the primary energy source for various industries and the demand for skilled labour was high (Werwatz, 2012) [30]. Most industries at that time moved from limited skilled labour to produce numbers of skilled and semi-skilled labour through apprenticeship. Therefore, they engaged different inexpensive employees, mostly teenagers and strong men. The intent of engaging youths was for them to become skilled at prime ages to serve the firm longer after apprenticeship. Though the apprentice labour was usually paid, their wages were meagre and inconsistent, and at some levels women were engaged for other jobs where fewer skills are required still with meagre stipends. Lulu and Riyanto (2011) [14] recounted that during the industrial revolution the condition of human labour, especially the apprentices, were close to slave labour, and they were made to pay for the skills they were acquiring. Their feeding, clothing and their lodgings are far from fair, and their affairs are of little concern to the organisations.

Things were noticeably better when numbers of institutions sprang up to graduate skilled labour who could operate some machines and were self-dependent in decision-making. Then, the apprenticeship programme that was industrial-centred shifted to an employees' development programme. Ryan et al. (2010) [22] accounted that in most cases after graduation from school at the age of fifteen to nineteen (depending on the type of school), students start an apprenticeship in their chosen professions. These graduates usually had better chances of being accepted as an apprentice for sophisticated craft professions or apprenticeships in white-collar related jobs such as finance or administration. One of the noticeable changes in apprenticeship after being taken over by institutions was a reduction in the length of apprenticeship, which was shortened from 7 years or more to $2.5-3.5$ years.

\section{The Benefits of Apprenticeship to Employers}

One of the beneficiaries of apprenticeship is the employer. Through apprenticeship, the firms gain highly skilled employees. Euwals and Winkelmann (2012) [7] expressed that organisations can benefit maximally from apprenticeship programmes by putting apprenticeships at the heart of the workforce planning. Ryan et al. (2010) argued that apprenticeships worked efficiently if they were introduced into the midst of other employees and plans were in place to make them team-up with another workforce. Thus, with the availability of standard apprenticeships across the broader range of business lines and specialisations, it becomes easier for the firm that embarks on apprenticeship to plan its workforce capacity around the apprentice. One assurance of apprenticeship is staff retention. Studies by Smith and Kemmis (2013) [25] and Olulu and Udeorah (2018) [18] established that staff retention is higher among the industrial-based trained staff than others. It is very unlikely for trained personnel to quit a firm for another after training as their specialisation is more likely to suit the operation of the initial firm. More so, it is highly expected that any organisation training its staff in-house will have offers for such staff, therefore, retaining the best of its staff instead of allowing them to depart the firm. One of the other benefits an organisation can amass from apprenticeship of employee is achieving effective leadership among employees.

Akpalu (2012) [2] argued that an organisation that trained its staff under the firm's roof is likely to have noticed the performance among the staff as well as discovering those staff with leadership traits which can make the organisation appoint them to leaders' roles.

Obi and Agh (2016) [17] opine that apprenticeship employees are likely to become a focal point in leadership and the directing of activities. Since it is the duty of the employers to create the contents and assessment materials for each standard of training, then it becomes relatively easier to determine those employees who have the rudiments of organisational skills and can act on behalf of the firm in a leadership capacity. Ryan et al. (2010) [22] showed that companies that have employees with diverse skills and experiences and skills do better than those that do not. An apprenticeship allows businesses to expose their employees to others with different experiences. It is not an understatement that apprenticeship allows widening of skills experiences for the employees.

Other benefits for employers through apprenticeship training included a reduction in turnover rates. Euwals and Winkelmann (2012) [7] expressed that turnover rates through apprenticeship cannot be compared to other forms of staff development. Likewise, Akpalu (2012) [2] identified cost-effectiveness, prompt results and appropriate skills acquisition as opportunities attached to apprenticeship training in any organisation. There is also a venue for the firm to offer customised training that meets industry standards for their employees. Such training is tailored towards particular skills or technicalities, and employers within a short period could 
boast of becoming expert in such aspects. An organisation that engages its employees in apprenticeship training could also achieve the increased knowledge transfer among its employees through on-the-job learning from an experienced mentor to others; such knowledge could also be supported with work-based learning. Ukenna, Ngozi, Anionwu and Olise (2010) [29] argued that firms that introduced apprenticeship training record higher employee retention rates. Ryan et al. (2010) [22] recounted that about $91 \%$ of apprentices prefer to continue working or choose to be employed in the same firm after their successful completion of training. An organisation can use apprenticeships to achieve a safer workplace that is likely to reduce significant compensation costs, due to the introduction of specific programmes on safety training during apprenticeship. The demand and supply of qualified skilled workers can be regulated, and its associative challenges could be addressed through an apprenticeship programme. There is no doubt that all organisations, irrespective of their discipline, will always want a systematic approach to training their staff to ensure their employees are well-equipped through training and certified to practise at the highest skill levels required for the occupation.

\section{The Benefits of Apprenticeship to Employees}

The following are the common benefits mostly pointed out by different authors and literature as opportunities gained by employees through apprenticeship training.

\section{Earn while learn}

When an individual enrols as an apprentice in a firm, there is always provision for some materials, learning incentives or remuneration as motivation for the apprenticeship. However, the organisation-based apprenticeship that is being organised for the employees caters for allowances of the employees throughout training. Thus, as an individual is learning, their payment, allowances, wages or salary are not to be stopped (Euwals and Winkelmann, 2012) [7].

\section{Training in the skills employers want}

Most of the times, organisations are convinced they need training when there is a vacuum in a particular skill, trade or production process, and when the firm resolves to send an employee on apprenticeship training, such an employee becomes an essential part of the firm; it could be hard to plan for cycle of production without him/her present or being neglected. Ukenna et al. (2010) [29] maintained that acquired specialised skills and training turn employees to gold compared to others within the organisation; he/she has just become an expert who has to be regarded and an authority who has to be listened to for proper guidance. When an employee arrives with new skills that are intensively needed within the firm, such an employee has to be motivated to stay within the firm, and the firm could not be in the position to deny him/her progression based on additional qualifications. According to Ryan (2010) [23] having completed an apprenticeship is an automatic enhancement of a staff $\mathrm{CV}$, which makes it difficult for the firm to play with his/her timely progression as means of motivation.

\section{Increased future earning potential}

As employees gain progression in their work due to apprenticeships so also the attached financial benefits increase. Owusu-Acheampong (2015) [19] argued that apprentice employees enjoy marked salary increases when they complete their training, since the organisation could not afford to lose their investment in paying for training and sponsoring the staff to allow such excellent skilled staff to depart for nothing. In order to retain the skills and production techniques within their firm, then financial benefits have to be immediately attached for the returning apprentice employees as motivation.

\section{Become more confident}

It is a usual experience that during training an employee may be feeling unsure of some skills and experiences. However, after training such an employee could become skilful, full of ideas and gain more confidence in him/herself. Ukenna et al. (2010) [29] argued that one of the main benefits of apprenticeship is to become more independent, confident and self-assured.

\section{Make new friends}

Being an apprentice in the workplace allows employees to meet new people, those in the category of knowledge and experiences ahead of him and those within or below his experience level. All these friends make him become better, share ideas while at work and become part of the network of experts (Ryan, 2010) [23].

\section{Concept of Small and Medium Enterprises}

The concept of small enterprise could be traced back to when man graduated from the nomadic lifestyle to a more settled life and engaged in fruit gathering and agriculture for his survival. From there, other sectors were explored in a bid to improve his standard of living (Pasanen, 2010) [20]. According to Demirbas, Hussain and Matlay (2011) [6], the most functional definition of small-scale business is the one given by the United Nations Industrial Development Organization (UNDO), which suggests that a small-scale business is one that possesses at least two of the following features.

1. Ownership and management are usually vested in the same individuals; that is, the management is not independent, and managers are usually 
also the owners.

2. The business controls a small share of the market and therefore constitutes a small quota in the large size market.

3. Capital is made available by the owner and policy decisions are in the hands of the individuals or small group of entrepreneurs.

4. The area of operation is localised, and workers concentrate on the local community; of course, some do have branches in other towns, but most of such branches serve as their depots.

5. The owner participates very actively in all decision-making on a day-to-day operational basis with a high degree of rigid control.

In Nigeria, there is no clear-cut definition that distinguishes a purely small-scale enterprise from a medium-scale enterprise. The Central Bank of Nigeria $(\mathrm{CBN})$, in its Monetary Policy Circular No. 22 of 1988, defined small-scale enterprises as having an annual turnover not exceeding 500,000 nairas. In the 1990 budget, the Federal Government of Nigeria defined small-scale enterprises for the purposes of commercial bank loans as those with an annual turnover not exceeding 500,000 nairas and, for Merchant Bank Loans, those enterprises with capital investments not exceeding 2 million nairas (excluding cost of land) or a maximum of 5 million nairas. The National Economic Reconstruction Fund (NERFUND) put the ceiling for Small Scale industries at 10 million nairas (Eze, 2012) [8].

In attempting to conceptualise small and medium enterprises (SMEs) in Nigeria, some points need to be stressed. First, there is no generally accepted definition of small or medium businesses because the classification of businesses into large, medium or small scale is a subjective and qualitative judgment. Secondly, small businesses are generally quite responsive to their environment, and our environment changes rapidly. Changes in the environment, therefore, affect what constitutes a small business at a particular point in time. Thirdly, the definition aims to set some limits (lower and upper) that will assist in achieving the set purpose. Such limits can be in terms of the level of capitalisation, sales volume, and number of employees among others (Sarosa and Zowghi, 2013) [24]. A clear definition may be useful in a particular national context, but it may not be practical to attempt a universal definition.

An attempt is made to present some definitions of SMEs to demonstrate the divergence in definition across countries. Baloyi (2010) [3] argued that it is quite possible, for instance, that within the same sector, a business can be 'small' by capitalisation but may not be deemed small by the number of people employed. Therefore, definitions and concepts of SMEs continue to evolve according to particular scholars, the environment, and disciplinary backgrounds as well as their perceptions of present-day realities. The CBN recently put the employment level of the small-scale businesses at less than 50 and medium-scale businesses as less than 100. In terms of asset-base, the small-scale has less than N1 million while medium scale has less than N150 million (Fatoki et al., 2010) [9]. The SMEs defined SME as any enterprise with a maximum asset base of N200 million excluding land and working capital and with the number of employees not less than ten or more than 300. Whichever approach is taken to define small-scale or medium-scale it has become evident that no clear distinct definition will succeed in creating a clear-cut margin between small scale- and medium-scale enterprises.

\section{THEORIETICAL BACKGROUND}

\section{Human capital theory by Gary Becker (1975)}

The human capital theory was propounded by Gary Becker in 1975. The theory focused on employees' human capital and its effect on earnings. According to Becker (1975) the firm, community or economy needs to gain human capital through accumulation of specific skills to the nature of the task. The human capital theorists believed that through human capital, there is an accumulation of skills desired for the task which are valuable to many firms requiring such transferable skills. The proponents of human capital theory such as Kenton (2011) [10] and Abel-Jaison and Deitz (2012) [1] maintained that the theory could be applied to job-assignment, wage dynamics, tournament, promotion and dynamics within firms. Thus, through human capital development a firm can attain the skills that are lacking or accomplish new design processes or new products.

\section{Experiential learning theory}

The experiential learning theory was propounded by David Kolb in 1984 [11]. Experiential theory expresses that learning is practical and results are prompt when an individual is exposed to knowledge that is created through the transformation of experience. Thus, the Experientialists argue that, to equip an individual effectively, the process has to include different hands-on combination knowledge grasped through transformation of experience. Thus, the approach of experiential learning theory differs from cognitive and behavioural theories in that cognitive theories emphasise the role of mental processes while behavioural theories ignore the possible role of subjective experience in the learning process. The experiential learning theorists maintained that learners retain and recall better whenever, they see, demonstrate and practise what they have learnt. The proponents of experiential learning theory such as Truluck and Courtenay in 1999 [27] and Miettinen in 2000 [16], argued that it is good in 
helping people explore their strengths when learning new things as well as addressing how learners can play to their strengths and developing areas in which they are weakest. Thus, both human capital theory and experiential theory established that an organisation can intentionally train its staff in the required skills or new aspect and such training could be very useful if being done practically. In short, for an organisation to gain more through staff training the training has to be closely monitored and practically based for prompt application.

\section{Empirical Review}

Owusu-Acheampong (2015) [19] examines the relationship between employee apprentices' human capital on their performance in small-scale businesses in the Sekondi-Takoradi Metropolis, Ghana. The specific objectives of the study were to determine the competencies of employees, examine the connection between these competencies and employees' performance and to determine the problems associated with the development of employees' competencies in small-scale businesses. The study used a descriptive survey research design. The study randomly sampled 153 employees across 15 small-scale business in the Sekondi-Takoradi Metropolis, Ghana. It used an interview guide as an instrument for data collection. Data were analysed using descriptive statistics while chi-square was used to find the associations between variables. The study revealed that education and training are significantly associated with increased productivity and enhanced the effectiveness and efficiencies of employees. The study revealed further that employees' knowledge and skills were significantly associated with performance dimensions such as improved quality, improved productivity and greater efficiency as well more effectiveness. The study also indicated some significant challenges inhibiting the development of employee competencies which are inadequate funds and lack of time for training activities. The study concluded that employees' apprenticeships influence their performance. The study recommended that the government through the Ministry of Trade and Industry, National Board for Small Scale Industries and Council for Technical and Vocational Education and Training (COTVET) should not diminish their efforts in supporting training programmes for the small business.

Lulu and Riyanto (2011) [14] carried out an empirical study to examine the importance of the apprenticeship training programme on the high-value leather product industries at Tanggulangin Sidoarjo, Indonesia. The study was based on a survey research design, where 115 employees of 10 leather product industries were randomly sampled comprising 30 top management staff and the remainder middle management staff. The study used a structured questionnaire for data collection, while data were analysed using the descriptive statistics methods. The findings from study established that most employees have not been involved in design making due to their limited experiences. Also, most employees did not participate in any apprenticeship training programme due to lack of support from both government and the organisation. The study concluded that productivity and creativity were low among leather factory employees due to a lack of necessary apprenticeship training. The study recommended that the government must intervene on the aspect of apprenticeship programmes to support the growth of the leather industries. Also, the study suggested that the management in leather industries should improve their human resource management through training such as apprenticeships where specific skills can be gained by employees.

Chris-Hasluck, Baldauf and Geoff (2015) [5] examine the net benefit of employer investment in apprenticeship training in England. The study was based on survey research design. The study randomly sampled 213 respondents comprising 78 top management staff and other staff from the different sectors of engineering, hospitality, retail, business administration, social care and construction. The study used a structured questionnaire and scale Proforma for data collection. The study analysed data using Pearson product-moment correlation and linear regression. It established that training of staff through apprenticeship improved product productivity and staff stability through higher retention rate. Also, it was reported in the study that the firm could earn both short and long-time benefits from apprenticeship training. The study recommended that all sectors should intensify staff training in the specific field and skills through apprenticeship for effective training costs and expected outcome.

Lerman (2014) [13] examined the effect of apprenticeship on the performance of nurses in a central Canadian medical hospital. The study was based on a descriptive survey research design. The study randomly sampled 230 nurses, comprised of 105 apprentice nurses and 125 institutional trained staff. The results used t-test and chi-square for data analysis. The study established that the management in the Canadian hospital is earning a more positive contribution from apprenticeship training nurses than others. It was also established that the investment in apprenticeship training for nurses is a long-term reward. Lerman (2014) [13] concluded that organisations such as hospital need many hands both qualified and semi-skilled to attend to numerous patients at various levels, therefore, investing in human capital development through apprenticeship is an investment that needs to be provided for and protected.

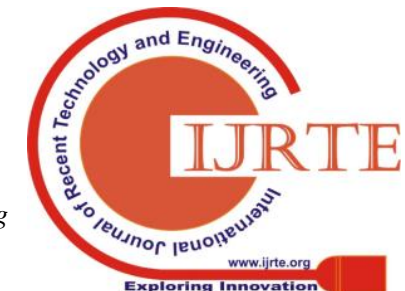


The study by Peter (2016) [21] examined the effect of the apprenticeship programme on the employees of Nestle company in South Africa. The study was based on a survey research design. The study sampled 69 employees comprising a mix of new entrants and existing employees who had once or sometimes participated in apprenticeships. The study used hands-on-experiment scale to determine the retention capacity of staff on skills and activities. The study used the t-test tool for data analysis. The study found that the length of apprenticeship related strongly with the performance of employees in Nestle Company. Also, it was established in the study that employees with more training exposure have higher manipulative skills than others. The study concluded that apprenticeship training was suitable for the activities of Nestle Company. Also, it was suggested that staff should be allowed to participate in more than one apprenticeship training to concretise their knowledge and skills as may be required by activities of the firm.

Udu (2015) [28] carried out an empirical study to examine the effects of apprenticeship orientation on performance of microbusinesses in Ebonyi State, Nigeria. The study adopted an exploratory survey research design which aimed to clarify new understandings in the study of apprenticeship as it benefits the small business. The study randomly sampled 301 microbusiness operators. The structured questionnaire was used for data collection. Data collected were analysed using Pearson's product-moment correlation, at $0.05 \mathrm{p}$-value. The study found that there was a positive relationship between long duration of learning through apprenticeship and microbusiness patronage. Also, it established that the persistence in training enhanced creativity and self-assurance among employees. The study concluded that microbusinesses positively benefit from apprenticeship programmes due to training of youthful and energetic staff. The study recommended that the operators of microbusinesses in Ebonyi State should explore more on apprenticeship training.

\section{METHODOLOGY}

This study adopt a survey design. The data for this study was obtained from primary and secondary sources. The population of the study consists of all employees of the small and medium enterprises registered with the Ministry of Commerce in Benue State, Nigeria. The study randomly sampled 228 employees from a total of 530 employees that indicated they had participated in an apprenticeship training system during a pre-study survey across 20 purposively selected SMEs in Benue State. The conditions for the selection of the small and medium enterprises were years of operation, staffing, and numbers of branches among others. The research instrument that was used for data gathering in this study is a structured questionnaire. The items for each construct are structured directly to address the research objectives. In the design of the questionnaire, the four (4) point Likert scale method was adopted. Data presentation and analysis was done using statistical tools such as descriptive tools which are simple percentage and average, while inferential statistics such Pearson Product Moment Correlation (PPMC) and linear regression analysis were used to test the hypotheses at 0.05 significant level.

\section{DATA PRESENTATION AND ANALYSIS OF RESULT FINDINGS}

$\mathbf{R Q}_{1}$ : Does the time spent by employees in apprenticeship influence the rate of task accomplishment in small and medium enterprises?

Table1: Employees' Perception of the Effect of Apprenticeship on Rate of Task Accomplishment in Small and Medium Enterprises, Benue State

\begin{tabular}{|c|c|c|c|c|c|c|c|}
\hline $\mathrm{S} / \mathrm{n}$ & Items & $\begin{array}{c}\mathrm{SA} \\
\mathrm{Fx}(\%)\end{array}$ & $\begin{array}{c}\mathrm{A} \\
\mathrm{Fx}(\%)\end{array}$ & $\begin{array}{c}\mathrm{D} \\
\mathrm{Fx}(\%)\end{array}$ & $\begin{array}{c}\mathrm{SD} \\
\mathrm{Fx}(\%)\end{array}$ & Avg & Rmk \\
\hline 1 & $\begin{array}{l}\text { The time spent in } \\
\text { apprenticeship } \\
\text { influences employees' } \\
\text { ability to meet } \\
\text { production timeframes }\end{array}$ & $112(52 \%)$ & $45(21 \%)$ & $23(11 \%)$ & $35(16 \%)$ & 3.09 & A \\
\hline 2 & $\begin{array}{l}\text { Given enough time by } \\
\text { the firm to partake in } \\
\text { apprenticeship } \\
\text { enhances the } \\
\text { employee's capability } \\
\text { to meet the customers' } \\
\text { demand }\end{array}$ & $59(27 \%)$ & $123(57 \%)$ & $12(6 \%)$ & $21(10 \%)$ & 3.02 & A \\
\hline 3 & $\begin{array}{l}\text { Spending enough time } \\
\text { during apprenticeship } \\
\text { enables the employee to } \\
\text { meet the design } \\
\text { specification }\end{array}$ & $92(43 \%)$ & $11(5 \%)$ & $56(26 \%)$ & $56(26 \%)$ & 2.65 & A \\
\hline 4 & $\begin{array}{l}\text { Employees who spend } \\
\text { enough time for } \\
\text { apprenticeship training } \\
\text { are likely to have the } \\
\text { ability to meet the } \\
\text { product delivery target }\end{array}$ & $43(20 \%)$ & $88(41 \%)$ & $32(15 \%)$ & $52(24 \%)$ & 2.57 & A \\
\hline
\end{tabular}

SA: strongly Agree, A: Agree, D: Disagree, SD: Strongly Disagree, Avg: Average, Rmk: Remark

The results in Table 1 give the perception of sampled SME employees about the effect of apprenticeship on the rate of task accomplishment in Benue State. The results showed that $52 \%$ of sampled SME employees expressed strongly that the time spent in apprenticeship influences employees' ability to meet the production timeframe (average $=3.09$ ). Also, 57\% of sampled employees from SMEs in Benue State expressed strongly that those employees given enough time to partake in apprenticeships can meet the customers' demand (average $=3.02$ ). Spending enough time during an apprenticeship programme influences employees' ability to meet the design specifications. This fact was established by $43 \%$ of the sampled employs across SMEs

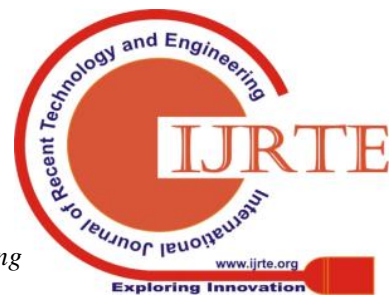


in Benue State (average $=2.65$ ). More so, $41 \%$ of sampled employees across SMEs in Benue State expressed that spending enough time during apprenticeship training is likely to influence the ability of employees to meet the product delivery target (average $=2.57$ ).

$\mathrm{RQ}_{2}$ : Does the number of times employees are allowed to partake in apprenticeship training influence their dedication to small and medium enterprises activities?

Table 2: Effects of Numbers of Time of Partaking in Apprenticeship on the Dedication of Employees to Activities in Small and Medium Enterprises

\begin{tabular}{|c|c|c|c|c|c|c|c|}
\hline Sin & Items & $\begin{array}{c}\text { SA } \\
\mathrm{Fx}(\%)\end{array}$ & $\begin{array}{c}\mathrm{A} \\
\mathrm{Ex}(\%)\end{array}$ & $\begin{array}{c}\mathrm{D} \\
\mathrm{Ex}(\%)\end{array}$ & $\begin{array}{c}\text { SD } \\
\mathrm{Fx}(\%)\end{array}$ & Avg & Rmk \\
\hline 4 & $\begin{array}{l}\text { Those staff who enjoy } \\
\text { timely apprenticeship are } \\
\text { dedicatedly in teamwork }\end{array}$ & $35(16 \%)$ & $101(47 \%)$ & $56(26 \%)$ & $23(11 \%)$ & 2.69 & A \\
\hline 2 & $\begin{array}{l}\text { When employees have } \\
\text { repeated apprenticeship } \\
\text { training, they are more } \\
\text { likely to be punctual at } \\
\text { work }\end{array}$ & $98(46 \%)$ & $78(36 \%)$ & $34(16 \%)$ & $5(2 \%)$ & 3.25 & A \\
\hline 3 & $\begin{array}{l}\text { It is a standard practice of } \\
\text { those employees who had } \\
\text { the opportunity to attend } \\
\text { different apprenticeship } \\
\text { programmes to show } \\
\text { readiness to follow orders }\end{array}$ & $54(25 \%)$ & $101(47 \%)$ & $29(13 \%)$ & $31(14 \%)$ & 2.83 & A \\
\hline 4 & $\begin{array}{l}\text { Employees who have } \\
\text { persistent apprenticeship } \\
\text { training are strong in } \\
\text { decision-making } \\
\text { participation }\end{array}$ & $67(31 \%)$ & $90(42 \%)$ & $32(15 \%)$ & $26(12 \%)$ & 2.92 & A \\
\hline
\end{tabular}

SA: strongly Agree, A: Agree, D: Disagree, SD: Strongly Disagree, Avg: Average, Rmk: Remark

Table 2 gives the results of the effects of frequency of partaking in apprenticeship training on the dedication of employee to activities in SMEs. The results showed that $47 \%$ of respondents expressed that those staff who enjoy appropriate apprenticeship training are more dedicated in teamwork than others (average $=2.69$ ). Also, $46 \%$ of employees of SMEs in Benue State expressed their agreement to the assertion that, whenever employees have punctual at work compared to others (average $=3.25$ ). More so, $47 \%$ of sampled employees expressed that it is standard practice for those employees who had the opportunity to attending different apprenticeship programmes to show readiness to follow orders (average $=2.83$ ). Likewise, $42 \%$ of sampled SMEs employees in Benue State expressed that those employees who have persistent apprenticeship training are more active in decision-making participation than others (average $=2.92$ ). repeated apprenticeship training, they are more like to be

\section{Testing of hypotheses}

$\mathrm{H}_{\mathrm{o} 1}$ : There is no significant relationship between the length of apprenticeship duration and rate of task accomplishment by employee in small and medium enterprises in Benue State

Table 3: Pearson Correlation Analysis on Relationship between Length of Apprenticeship Duration and Rate of Task Accomplishment by Employees in Small and Medium Enterprises in Benue State

\begin{tabular}{|c|c|c|c|c|}
\hline Stat & & $\begin{array}{l}\text { Asymp. } \\
\text { Std. Errora }\end{array}$ & $\begin{array}{l}\text { Approx. } \\
\mathrm{T}^{\mathrm{b}}\end{array}$ & $\begin{array}{l}\text { Approx. } \\
\text { Sig. }\end{array}$ \\
\hline Pearson's R & .619 & .041 & 11.496 & $.000^{c}$ \\
\hline $\begin{array}{l}\text { Length of time spent as an } \\
\text { Eta }^{2} \text { apprentice }\end{array}$ & .565 & & & \\
\hline Rate of task accomplishment & .501 & & & \\
\hline N of Valid Cases & 215 & & & \\
\hline
\end{tabular}

a. Not assuming the null hypothesis.

b. Using the asymptotic standard error assuming the null hypothesis.

c. Based on normal approximation.

Table 3 shows the results of the correlation analysis on the relationship between length of apprenticeship duration and rate of task accomplishment by employee in SMEs in Benue State. The results indicated a Pearson R-value of 0.619, Eta ${ }^{2}$ values 0.565 and $0.501, \mathrm{P}$-value of 0.00 . Thus, since the calculated p-value $(0.00)$ is less than hypothetical $\mathrm{p}$-value (0.05), this shows a strong relationship between the length of time spent as an apprentice and the rate of task accomplishment by employee. Also, the eta squared value of 0.567 indicated that the length of time spent as an apprentice explains about a $56.5 \%$ variation in the rate of task accomplishment by SME employees in Benue State. Therefore, the study rejected the null hypothesis. This implies that the length of time spent as apprentice by employees significantly influences their competency in term of task accomplishment in Benue State.

$\mathrm{H}_{\mathrm{o} 2}$ : Frequency of partaking in apprenticeship training does not significantly influence employee dedication to organisational activities among small and medium enterprises in Benue State.

Table 4: Linear Regression Analysis on effect of frequency of Partaking in apprenticeship training and employee dedication to activities among small and medium enterprises in Benue State 


\begin{tabular}{|c|c|c|c|c|c|}
\hline \multirow[t]{2}{*}{ Model } & \multicolumn{2}{|c|}{$\begin{array}{l}\text { Unstandardised } \\
\text { Coefficients }\end{array}$} & $\begin{array}{l}\text { Standardised } \\
\text { Coefficients }\end{array}$ & $\mathrm{T}$ & Sig. \\
\hline & B & Std. Error & Beta & & \\
\hline (Constant) & 2.168 & .174 & & 12.46 & .018 \\
\hline $\begin{array}{l}\text { Freq. of partaking in } \\
\text { apprenticeship }\end{array}$ & 2.572 & .187 & .687 & 13.781 & .000 \\
\hline
\end{tabular}

Dependent Variable: Job dedication, F-ratio ${ }_{1,213}$ (189.922), p-value (0.000), $R=0.687, R^{2}(0.471)$, Adjust $R^{2}(0.469)$

Table 4 gives the results of linear regression analysis on the effect of frequency of partaking in apprenticeship training on job dedication of SMEs employee in Benue State, Nigeria. The result showed a standardised coefficient (Beta) of 0.687 , $\mathrm{t}$-value of 13.781 , P-value of 0.000 . Since the calculated p-value (0.000) is less than the hypothetical p-value of 0.05 (i.e. $p$-calculate value: $0.000<p$-value: 0.05 ) this implied a significant positive influence of frequency of partaking in apprenticeship training by SME employees on their job dedication in Benue State. The null hypothesis is therefore rejected. Also, the adjusted R-square 0.469 indicated about 46.9 variation in job dedication among employees of SMEs in Benue State which could be explained by their frequency of participation in apprenticeship training. Also, the coefficient B of 2.572 suggested the prediction power of frequency participation in apprenticeship training on the employee dedication of activities of SMEs in Benue State.

\section{DISCUSSION OF FINDINGS}

The time spent by employees in apprenticeship significantly influences the rate of task accomplishment in small and medium enterprises. Precisely, it enhanced their ability to meet production timeframes, meet customers' demands, adjust to the design specification as well as enhance their product delivery. This concurs with the findings earlier made by Chris-Hasluck et al. (2015) [5] and Smith and Kemmis (2013) [25] that apprenticeship significantly promotes performance through abilities to handle various activities. Also, the current study concurs with the conclusion drawn by Akpalu (2012) [2] that apprenticeship is an eye-opener training for the employees to upgrade their competency as well as enhance their rate of task accomplishment. One of the essential aspects of the apprenticeship programme is the ability to reposition the employees to know the demands on them at every stage of production. This agreed with the recent submission made by Olulu and Udeorah (2018) [18] that, with apprenticeship, employees can develop their experiences to their full strength.

The frequency of apprenticeship training attended by employees of SMEs in Benue State correlated firmly with their competency and dedication to jobs. This was among the findings revealed in this study. The experiences gathered due to interaction with others during training as well special skills allocated in training significantly enhanced an employee's punctuality to work, readiness to take orders as well as participating in healthy decision-making. This affirmed the earlier conclusions drawn by Lerman (2014) [13] that repeated exposure of staff to hands-on practices enhances their overall competency and dedication. Also, studies by Smith and Kemmis (2013) [25] and Ukenna et al. (2010) [29] established that the more the staff enjoy training and development programmes the more they develop a sense of belonging. Also, Chris-Hasluck et al. (2015) [5] expressed that training and re-training is the best way of repositioning the employees at affordable costs and within a sensible time frame.

\section{CONCLUSION}

The current study has shown through its findings that apprenticeship training improved the performance of employees in small and medium enterprises in Benue State. Specifically, this study has confirmed that through apprenticeship the employees improve on their task accomplishment. Also, the hands-on training given to small and medium enterprise employees in Benue State is accountable for improving the performance efficiency of employees irrespective of their trade.

The frequency of apprenticeship training attended by employees of small and medium enterprises in Benue State correlated firmly with their competency and dedication to jobs. This was among the findings revealed in this study. The experiences gathered due to interaction with others during training develop their sense of belonging. Above all, this study has reaffirmed the importance of training and re-training for the employees primarily through apprenticeship as a way of creating sense of belonging and staff dedication.

\section{RECOMMENDATIONS}

Based on the findings and conclusion drawn in this study, the following are the recommendations:

1. The small and medium enterprises operators in Benue State should ensure that they organise hands-on training (apprenticeships) for their employees to improve their competency.

2. Efforts should be put in place by the small and medium enterprises operators in Benue State to ensure that their employees are benefiting from organised training without favouritism for distributed effectiveness and skill development among employees. 


\section{REFERENCES}

[1] R. Abel-Jaison \& R. Deitz, (2012). "Do colleges and universities increase their region's human capital?". Journal of Economic Geography, vol 12 (3) $p 667$.

[2] L. Akpalu, (2011). National apprenticeship programme launched. The Ghanaian Times. Accra.

[3] J.K. Baloyi, "An analysis of constraints facing smallholder farmers in the agribusiness value chain: A case of farmers in Limpopo province," Master's Thesis, Unpublished. University of Pretoria, Pretoria, 2010.

[4] Z. Bilal, Export incentives, financial constraints, and the misallocation of credit: micro-level evidence from subsidized export loans," Journal of Financial Economics, vol 2(3), pp.34 - 45, 2009

[5] T.H. Chris-Hasluck, B. Baldauf, \& B. Geoff, (2015). The net benefit to employer investment in apprenticeship training. Institute for Employment Research

[6] D. Demirbas, J.G, Hussain, \& H. Matlay, (2011). Owner-managers' perceptions of barriers to innovation: empirical evidence from Turkish SMEs. Journal of Small Business and Enterprise Development, 18(4):764- 780 .

[7] R. Euwals, \& R. Winkelmann, (2012). Mobility after apprenticeship evidence from register data. Applied Economics Quarterly. 48 (3-4)

[8] T. C. Eze, (2012). The problems and prospects of management of small-scale business in Nigeria. MSc Thesis, University of Nigeria Enugu.

[9] O.O. Fatoki, \& D. Garwe, (2010). Obstacles to the Growth of New SMEs in Africa Countries: A principal component analysis approach. African Journal of Business Management, 4: 729-738.

[10] W. Kenton, (2011). Human capital. Retrieved on 2019-11-12 from https://www.investopedia.com/terms/h/humancapital.asp.

[11] D. A. Kolb, (1984). Experiential learning: Experience as the source of learning and development. New Jersey: Prentice-Hall.

[12] D. A. Kolb, R. E. Boyatzis, \& C. Mainemelis, (2000). Experiential learning theory: previous research and new directions. Perspectives on cognitive, learning, and thinking styles. Sternberg \& Zhang (Eds.). NJ: Lawrence Erlbaum.

[13] R. I. Lerman, (2014). Expanding apprenticeship training in Canada. One of a series of reports commissioned for Taking Action for Canada: Jobs and Skills for the 21 st Century, an initiative of the Canadian Council of Chief Executives (CCCE).

[14] S. Lulu, \& B. N. Riyanto, (2011). The importance of apprenticeship training program as the backbone of high-value leather products industries at Tanggulangin Sidoarjo Indonesia. International Journal of Education and Management Technology, 1(3), 20 - 31

[15] M.A. Mahmoud, (2011). Market orientation and business performance among SMEs in Ghana. International Business Research, 4(1) 241-251.

[16] R. Miettinen, (2000) The concept of experiential learning and John Dewey's theory of reflective thought and action, International Journal of Lifelong Education, 19(1), 54-72.

[17] F. Obi, \& N. C. Agha, (2016). Apprenticeship practices and sustainable economic growth in Nigeria: A study of a selected automobile mechanic, workshops in Lagos State. International Journal of Development Research, 6(2), 6765-6773.

[18] R. M. Olulu, \& S. A. F. Udeorah, (2018). Contract of Apprenticeship and Employment Generation in Nigeria. International Journal of Scientific Research in Education, 11(3), 335-344.

[19] E. Owusu-Acheampong, (2015). Examining the relationship between employees/apprentices human capital on their performance in small scale businesses in the Sekondi-Takoradi metropolis, Ghana. International Journal of Small Business and Entrepreneurship Research, 3(1), 1 - 9.

[20] M. Pasanen, (2010). SME Growth Strategies: A Comparison of Young and Long-lived Firms. PhD Thesis, Unpublished. University of Kuopio, Kuopio.

[21] B.L. Peter, (2017). Impact of apprenticeship on the performance of Nestles staff in South African. The Nestlé People Development Review 2(3), 123 $-147$
[22] PRyan, K. Wagner, S. Teuber \& U. Backes-Gellner (2010). Trainee Pay in Britain, Germany and Switzerland: Markets and Institutions SKOPE Research Paper No. 96 July

[23] P. Ryan (2010). The Attributes and Institutional Requirements of Apprenticeship: Evidence from Smaller EU Countries International Journal of Training and Development, 2(3), 23 - 33.

[24] S. Sarosa, \& D. Zowghi, (2013). Strategy for Adopting Information Technology for SMEs: Experience in Adopting Email within an Indonesian Furniture Company. Electronic Journal of Information Systems Evaluation, 6(2), 165-176.

[25] E. Smith \& R. B. Kemmis (2013). Towards a model apprenticeship framework. Industrial Relations Journal 39:5 428-447

[26] H. Steedman, (2011). Challenges and change: apprenticeships in German-speaking Europe ee in Dolphin T.and T. Lanning (eds) Rethinking Apprenticeships Institute for Public Policy Research (IPPR) London.

[27] J. E. Truluck, \& B. C. Courtenay (1999). Learning Style Preferences among Older Adults. Educational Gerontology, 25(3), 221-236.

[28] A.A. Udu (2015). Apprenticeship orientation and performance of microbusinesses in Ebonyi State, Nigeria. European Journal of Biology and Medical Science Research, 3(6)1-11

[29] S. Ukenna, N. Ngozi, C. Anionwu \& M.C. Olise (2010), Effect of investment in human capital development on organisational performance: Empirical examination of the perception of small enterprise owners in Nigeria. European Journal of Economics, Finance and Administrative Sciences,

[30] A. Werwatz (2012). Occupational mobility after apprenticeship -How effective is the german apprenticeship system? Applied Economics Quarterly, Vol. 48 No. 3-4.

[31] S C. Wolter \& R. Paul (2011). Apprenticeship. In Eric A. Hanushek, Stephen Machin, and Ludger Woessmann (eds.). Economics of Education, Handbooks in Economics. The Netherlands: North-Holland. 3, 521-576. 